\title{
Fixed Interest Player v/s Floating Interest Player: Tug of War
}

\author{
Naseem Ahamed \\ IBS Hyderabad, IFHE University, Hyderabad, India \\ Email: naseemahamed@ibsindia.org
}

Received 30 June 2015; accepted 1 August 2015; published 4 August 2015

Copyright (C) 2015 by author and Scientific Research Publishing Inc.

This work is licensed under the Creative Commons Attribution International License (CC BY). http://creativecommons.org/licenses/by/4.0/

c) (i) Open Access

\begin{abstract}
Swaps have been one of the most widely used derivatives since 1970s and for good reasons. Interest rate swap is a mutual agreement between two parties to pay each other the differential amount of up and above the fixed $\mathrm{v} / \mathrm{s}$ LIBOR. This paper tries to answer the long standing question of what should have been the range around which the fixed rate should have hovered with respect to fluctuating LIBOR over the years to attain break-even and not to be worse off. This paper analyses for the difference in the average LIBOR of various periods (1 month, 3 months, 6 months and 12 months) with respect to different maturity dates (5 years, 10 years, 15 years, 20 years and 23 years). It looks for the presence of structural change in the trend of LIBOR beginning from 1990 to 2013. This paper will draw the attraction of academic as well as market participants. Fixed rate player refers to the party which agrees to pay the existing floating rate (LIBOR) in the market in exchange of an agreed upon fixed rate from the counter party and vice-versa.
\end{abstract}

Keywords

Derivatives, LIBOR, Break-Even, Structural Change, Fixed Rate

\section{Introduction}

In credit derivatives swap, two companies known as party and counterparty enter into an agreement mutually accepted and legally binding upon each other where the fixed rate player agrees to pay a fixed rate of a pre-decided notional amount to the floating rate player in exchange for the floating rate (LIBOR).

Both the parties have their views about the state of the economy in future and its impact on the interest rates. The fixed rate player expects much volatility in the interest rates and hence locks his payment by adhering to a fixed payment whereas the floating rate player anticipates the economy to remain relatively unchanged and hence pegs his payment schedule according to floating rate. 
The economy however, charts its own course and is either relatively stable over a period or fluctuates making one of the two parties better off than other. The following example illustrates the concept in a lucid manner.

A company named Fixer Ltd. enters into an agreement with another company named Floater Ltd. to pay a fixed interest rate of (say 5\% annually) the notional amount of \$100 million in exchange for receiving floating payments from the Floater Ltd. at the existing 12 months LIBOR rate over the same notional amount. Let the 12 months LIBOR rate at time $t$ is 7\%, then Fixer Ltd. pays $\$ 5$ million to Floater Ltd. in exchange for $\$ 7$ million.

This arrangement is made for a certain period of time and the notional amount never comes into picture but for calculating interest payment. Over a period of time one party may have advantage over the other, as it was able to anticipate the future economic scenario better than the other. The objective of this paper is fourfold and those can be delineated as follows:

a) To find out the break-even rate for a period of 5, 10, 15, 20, 23 years of 1 month, 3 months, 6 months and 12 months credit swap agreements between Fixed and Floating rate player;

b) To find out if there occur any structural changes in the trend of credit swap over the given period and possible explanations for them if any.

c) To forecast with reasonable accuracy the trend of credit swap agreements based on historical data;

d) To find out if there exists, a correlation of LIBOR rates with the stock market index (DJIA).

Corresponding to the above mentioned objectives and voids in the existing literature; the following hypotheses are postulated:

\section{Literature Review}

Interest rate swap has been a topic which has not been thoroughly researched (Brown, Harlow, Smith 1994) [1], in the academic literature and hence this topic warrants some more attention. Since swaps are a private and over the market exercise, even data is difficult to get about these transactions. Swap spread was found in the above mentioned paper with respect to comparable maturity yield of treasury bond and the pricing mechanism of short term swaps were found to be substantially different from that of long term swaps.

Kiff Ron and Ebrahim (Bank of Canada Review 2000-2001) [2] discuss about the characteristics of the swap agreements, valuation and risk management by governments. Bicksler et al. 1986 [3] studies about interest rate swaps and their economic analysis.

A "plain vanilla" interest rate swap is a company agrees to pay cash flows equal to interest at a predetermined fixed rate on a notional principal for a number of years (Hull, 2005) [4]. In other words, one party promised to pay a fixed rate of interest (swap rate) while the other party promises to pay a fixed rate of interest rate at each periodic interval in a simple fixed/floating rate swap. An interest rate swap can be used to transform a floatingrate loan into a fixed-rate loan or vice-versa.

The paper by Grinblatt (2001) [5], titled "An analytic solution for interest rate swap spreads", argues that the liquidity differences between government securities and short-term Eurodollar borrowings account for interest rate swap spreads. This paper discusses about the reasons for the existence of the spread, and constitutes models to fit the data. The parameters of the model were estimated utilizing weekly data on term structure of swap spreads, across many countries. It however does not contrast the long run superiority of one over the other.

Titman and Sheridan, 1992 [6] studies it from the perspective of choice of finances with respect to interest rate swaps. It expounds on the impact of firms decision to borrow either for long or short term in presence of an active swap market. The model used by them highlights the increase in demand of fixed for floating rate and reduction in demand of floating for fixed rate in presence of asymmetric information. Turnbull, 1987 [7] studies the characteristics of swaps and delineates the differences of swaps with other derivative instruments. Wall et al. 1989 [8] on the other hand explains the difference of swaps and its advantages from comparable debt contract.

Duffie and Singleton (1997) [9], in their famous article "An econometric model of the term structure of Interest-Rate swap yields", plugged one of the notable voids in the existing literature by building a multifactor econometric model of the term-structure of interest rate swaps, robust enough to accommodate for counterparty default risk and differences in the liquidity of Swap markets and Treasury. This article too addressed the swap pricing concern under different restrictions.

After analyzing substantial existing literature over the topic, it was found that there have been papers on various aspects of swaps as such, but the very idea of what should have been the disposition of the fixed rate player, in the wake of ever changing LIBOR for them to be benefitting out of the arrangement is missing in the existing literature. 


\section{Hypothesis}

1. There occurs no structural change in the interest rate trend of credit swap over the years.

2. There is no significant difference between the mean/median rates of 5 years, 10 years, 15 years, 20 years and 23 years credit swap of 1 month, 3 months, 6 months and 12 months period.

3. There is no significant difference between the mean/median rates in credit swap of 1 month, 3 months, 6 months and 12 months period.

4. There is not significant correlation between LIBOR rates and DJIA index for the corresponding period.

This paper takes into account the swap agreements of companies for 23 years beginning from 1989 till 2013 for 1 month/3 months/ 6 months/12 months LIBOR and corresponding fixed rate annual/ semi-annual payments.

The available data for various LIBOR rates (1 month/3 months/6 months/12 months) from January 1990 till January 2013, indicates that the break even rate for the fixed rate player should have been 3.73\%, 3.86\%, 4.01\%, 4.22\% respectively for the LIBOR rates ( 1 month/3 month/6 month/12 month) for a contract spanning over the entire period of 23 years. The fixed rate player are better off than the floating rate player, if it pays less than the above mentioned break even rates for the corresponding periods and vice-versa.

The break even rates between fixed rate player and its counterpart for the four types of LIBOR (1 month, 3 months, 6 months and 12 months) for various time duration (5 years, 10 years, 15 years and 20 years) are demonstrated below in Table 1.

Table 1. Exhibiting the break even rate of credit swap agreements. The table could be read as: The break even rate for 1 month LIBOR for the fixed v/s floating rate player for a period of 5 year from 1990-1995 is 5.22\%, for a period of 10 years from $1990-2000$ is $5.40 \%$, for a period of 15 years from $1990-2005$ is $4.56 \%$ and for a period of 20 years from 1990 to 2010 is $4.25 \%$.

\begin{tabular}{|c|c|c|c|c|}
\hline 5 years $/ 10$ years $/ 15$ years/20 years & $\begin{array}{c}1 \text { month } \\
\text { break-even rate (\%) }\end{array}$ & $\begin{array}{l}\text { 3 months } \\
\text { break-even rate (\%) }\end{array}$ & $\begin{array}{l}6 \text { months } \\
\text { break-even rate (\%) }\end{array}$ & $\begin{array}{l}12 \text { months } \\
\text { break-even rate (\%) }\end{array}$ \\
\hline 1990-1995/1990-2000/1990-2005/1990-2010 & $5.22 / 5.40 / 4.56 / 4.25$ & $5.55 / 5.61 / 4.68 / 4.38$ & $6.02 / 5.88 / 4.87 / 4.52$ & 7.05/6.39/5.19/4.72 \\
\hline 1991-1996/1991-2001/1991-2006/1991-2011 & $4.75 / 5.21 / 4.25 / 3.85$ & $5.06 / 5.41 / 4.39 / 3.99$ & $5.49 / 5.67 / 4.61 / 4.14$ & 6.36/6.06/4.94/4.33 \\
\hline 1992-1997/1992-2002/1992-2007/1992-2012 & 4.67/4.97/4.21/3.57 & $4.94 / 5.09 / 4.34 / 3.70$ & $5.31 / 5.28 / 4.53 / 3.84$ & $6.09 / 5.57 / 4.82 / 4.02$ \\
\hline 1993-1998/1993-2003/1993-2008/1993-2013 & $5.07 / 4.77 / 4.30 / 3.40$ & 5.33/4.88/4.41/3.52 & $5.71 / 5.05 / 4.57 / 3.67$ & $6.32 / 5.25 / 4.74 / 3.83$ \\
\hline 1994-1999/1994-2004/1994-2009 & $5.52 / 4.57 / 4.24$ & $5.76 / 4.67 / 4.37$ & $6.10 / 4.82 / 4.49$ & $6.59 / 5.02 / 4.61$ \\
\hline 1995-2000/1995-2005/1995-2010 & $5.68 / 4.28 / 3.96$ & $5.98 / 4.41 / 4.10$ & $6.42 / 4.63 / 4.25$ & $7.18 / 4.98 / 4.43$ \\
\hline 1996-2001/1996-2006/1996-2011 & $5.77 / 4.04 / 3.58$ & $6.03 / 4.19 / 3.72$ & $6.39 / 4.44 / 3.87$ & $6.79 / 4.75 / 4.00$ \\
\hline 1997-2002/1997-2007/1997-2012 & $5.36 / 4.02 / 3.23$ & $5.53 / 4.17 / 3.38$ & $5.83 / 4.42 / 3.54$ & $6.23 / 4.77 / 3.72$ \\
\hline 1998-2003/1998-2008/1998-2013 & $4.57 / 3.96 / 2.87$ & $4.72 / 4.09 / 3.02$ & 4.99/4.30/3.19 & $5.34 / 4.52 / 3.38$ \\
\hline 1999-2004/1999-2009 & $3.70 / 3.64$ & $3.82 / 3.80$ & $4.04 / 3.94$ & $4.48 / 4.14$ \\
\hline $2000-2005 / 2000-2010$ & $2.97 / 3.15$ & $3.13 / 3.31$ & $3.46 / 3.48$ & $4.11 / 3.71$ \\
\hline 2001-2006/2001-2011 & $2.41 / 2.53$ & $2.63 / 2.70$ & $3.03 / 2.88$ & $3.77 / 3.13$ \\
\hline 2002-2007/2002-2012 & $2.70 / 2.18$ & $2.91 / 2.35$ & $3.21 / 2.49$ & $3.80 / 2.71$ \\
\hline 2003-2008/2003-2013 & $3.38 / 2.03$ & $3.54 / 2.20$ & $3.74 / 2.36$ & $4.00 / 2.55$ \\
\hline 2004-2009 & 3.61 & 3.83 & 3.97 & 4.09 \\
\hline 2005-2010 & 3.37 & 3.63 & 3.79 & 3.97 \\
\hline 2006-2011 & 2.73 & 3.01 & 3.22 & 3.48 \\
\hline 2007-2012 & 1.75 & 2.05 & 2.30 & 2.71 \\
\hline $2008-2013$ & 0.75 & 1.07 & 1.35 & 1.79 \\
\hline
\end{tabular}




\section{Data and Methodology}

The data required for this article were mostly secondary and quantitative. The historical data of floating rate of LIBOR for different maturity periods has been extracted from the Reuters database and some of them were also taken from the WRDS (Wharton Research Data Services) CRSP (The centre for Research in Security Prices. Official website of NYSE was also visited to check the security prices data. The duration of data is from 1990 to 2013.

The methodology used in this paper is the " $\mathrm{z}$ ” test for comparison of mean/median between two samples.

\section{Results}

In fulfillment of the first objective (a), the break-even rate for all the above mentioned periods for all duration credit swaps are illustrated in Table 1.

Objective (b) and hypothesis (1) the hypothesis that there exists no structural change in the average LIBOR over the period from 1990-2013 gets rejected at 95\% confidence interval. The F value lies in the rejection region. This means that there are structural changes in the average LIBOR over the period 1990-2013. The change could be because of many plausible reasons outlined below:

a) As it is evident from Table 2 that the average LIBOR has a negative correlation with the market index (in this case DJIA), it makes sense that in the year 2000 the Dow Jones and the Nasdaq hit an all-time record high till then at 11722.98 and 5048.62 respectively, which could have affected LIBOR in taking a nose dip because of the negative correlation with the index.

b) The dot com bubble busted during this time which had its climax on 10 March 2000 with the NASDAQ peaking at 5132.52, was a period during which "stock markets in Western nations saw their value increase rapidly from growth in the new Internet sector and related fields".

c) United States invaded Iraq was because Saddam Hussein in the year 2000 went ahead with its plans to stop using the U.S. dollar in its oil business and start using the euro. Iraq switching from the US Petro-dollar to the euro meant that countries would no longer be obligated to buy oil in US dollars, so they would no longer have to maintain their US dollar reserves. Since reaching a double top in the year 2000/01, the US dollar has been devalued approximately 50\% relative to the euro (the euro has gained more than $90 \%$ from its low).

To achieve the objective (c), the average of 1 month, 3 months, 6 months and 12 months rate was taken as their values were extremely close to each other coupled by the fact that they were strongly correlated. See Graph 1. The future swap rates were forecasted based upon the historical rates and its dependence with Dow Jones Industrial Average from January 1990 till January 2013. The forecasted values are for 1 month, 2 months, 3 months... up to 12 months. These values are given in Table 3.

For objective (d) and hypothesis (4), the correlation between DJIA and Average LIBOR rates are displayed in Table 2. It shows an inverse relationship between these two variables. The significance of the correlation coefficient is also tested to find out if the calculated correlation is significantly different from 0 or not. This was tested with the test statistic: and the $t$ calculated was found to be -8.686 , while the $t$ critical value for the corresponding degrees of freedom is 1.97. Since the calculated value is way far from the tabulated value of $t$ and lies in the rejection region. So the hypothesis that coefficient of correlation is 0 , gets rejected and it is concluded that the correlation between the average LIBOR and closing prices if DJIS is significant.

For hypothesis (2), Table 4 is presented in which LIBOR of none of the 1 month, 3 months, 6 months and 12 months for a period of 5 years, 10 years, 15 years, 20 years and 23 years are significantly different from each other.

For hypothesis (3), Table 5 is presented in which LIBOR of none of the 1 month, 3months, 6 months and 12 months are significantly different from each other.

Table 2. Exhibits correlation between LIBOR rate and DJIA index for the period under study.

\begin{tabular}{ccc}
\hline & Column 1 & Column 2 \\
\hline Column 1 & 1 & \\
Column 2 & -0.46418 & 1 \\
\hline
\end{tabular}




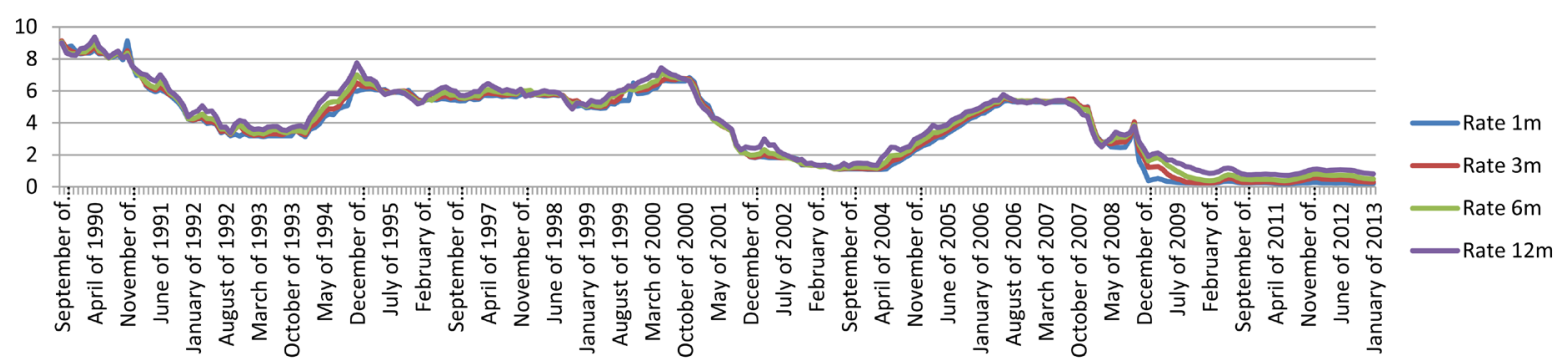

Graph 1. Exhibiting the consonance among rates of different months.

Table 3. Recent trend in the credit swap rate has been hovering around 6.52\%.

Feb. 2013 Mar. 2013 Apr. 2013 May 2013 June 2013 July 2013 Aug. 2013 Sept. 2013 Oct. 2013 Nov. 2013 Dec. 2013 Jan. 2014

$\begin{array}{llllllllllll}6.5231 & 6.5228 & 6.5225 & 6.5222 & 6.5219 & 6.5216 & 6.5213 & 6.5210 & 6.5206 & 6.5203 & 6.5200 & 6.5197\end{array}$

Table 4. Table to analyze possible structural break in credit swap of 5, 10, 15, 20 and 23 year period.

\begin{tabular}{|c|c|c|c|c|c|c|c|}
\hline & & $1 \mathrm{v} / \mathrm{s} 3$ months & $1 \mathrm{v} / \mathrm{s} 6$ months & $1 \mathrm{v} / \mathrm{s} 12$ months & $3 \mathrm{v} / \mathrm{s} 6$ months & $3 \mathrm{v} / \mathrm{s} 12$ months & $6 \mathrm{v} / \mathrm{s} 12$ months \\
\hline \multirow{4}{*}{$\begin{array}{l}\mathrm{Z} \text { value for } \\
\text { difference in } \\
\text { mean for } 5 \\
\text { year period }\end{array}$} & $\mathrm{P}(\mathrm{Z}<=\mathrm{z})$ one-tail & 0.475976 & 0.451457 & 0.409543 & 0.475461 & 0.433122 & 0.457255 \\
\hline & z Critical one-tail & 1.644854 & 1.644854 & 1.644854 & 1.644854 & 1.644854 & 1.644854 \\
\hline & $\mathrm{P}(\mathrm{Z}<=\mathrm{z})$ two-tail & 0.951952 & 0.902914 & 0.819086 & 0.950922 & 0.866244 & 0.91451 \\
\hline & z Critical two-tail & 1.959964 & 1.959964 & 1.959964 & 1.959964 & 1.959964 & 1.959964 \\
\hline \multirow{4}{*}{$\begin{array}{l}\mathrm{Z} \text { value for } \\
\text { difference in } \\
\text { median for } 5 \\
\text { year period }\end{array}$} & $\mathrm{P}(\mathrm{Z}<=\mathrm{z})$ one-tail & 0.484872 & 0.454429 & 0.429273 & 0.46949 & 0.44418 & 0.474491 \\
\hline & z Critical one-tail & 1.644854 & 1.644854 & 1.644854 & 1.644854 & 1.644854 & 1.644854 \\
\hline & $\mathrm{P}(\mathrm{Z}<=\mathrm{z})$ two-tail & 0.969744 & 0.908858 & 0.858546 & 0.938979 & 0.88836 & 0.948983 \\
\hline & z Critical two-tail & 1.959964 & 1.959964 & 1.959964 & 1.959964 & 1.959964 & 1.959964 \\
\hline \multirow{4}{*}{$\begin{array}{l}\mathrm{Z} \text { value for } \\
\text { difference in } \\
\text { mean for } 10 \\
\text { year period }\end{array}$} & $\mathrm{P}(\mathrm{Z}<=\mathrm{z})$ one-tail & 0.47167 & 0.442195 & 0.388394 & 0.470365 & 0.415587 & 0.44449 \\
\hline & z Critical one-tail & 1.644854 & 1.644854 & 1.644854 & 1.644854 & 1.644854 & 1.644854 \\
\hline & $\mathrm{P}(\mathrm{Z}<=\mathrm{z})$ two-tail & 0.943341 & 0.884391 & 0.776788 & 0.940729 & 0.831174 & 0.88898 \\
\hline & z Critical two-tail & 1.959964 & 1.959964 & 1.959964 & 1.959964 & 1.959964 & 1.959964 \\
\hline \multirow{4}{*}{$\begin{array}{l}\mathrm{Z} \text { value for } \\
\text { difference in } \\
\text { median for } 10 \\
\text { year period }\end{array}$} & $\mathrm{P}(\mathrm{Z}<=\mathrm{z})$ one-tail & 0.475296 & 0.448091 & 0.394484 & 0.47267 & 0.418215 & 0.444864 \\
\hline & z Critical one-tail & 1.644854 & 1.644854 & 1.644854 & 1.644854 & 1.644854 & 1.644854 \\
\hline & $\mathrm{P}(\mathrm{Z}<=\mathrm{z})$ two-tail & 0.950593 & 0.896183 & 0.788968 & 0.94534 & 0.836431 & 0.889728 \\
\hline & z Critical two-tail & 1.959964 & 1.959964 & 1.959964 & 1.959964 & 1.959964 & 1.959964 \\
\hline \multirow{4}{*}{$\begin{array}{l}\mathrm{Z} \text { value for } \\
\text { difference in } \\
\text { mean for } 15 \\
\text { year period }\end{array}$} & $\mathrm{P}(\mathrm{Z}<=\mathrm{z})$ one-tail & 0.436517 & 0.373104 & 0.268005 & 0.434128 & 0.321053 & 0.382515 \\
\hline & z Critical one-tail & 1.644854 & 1.644854 & 1.644854 & 1.644854 & 1.644854 & 1.644854 \\
\hline & $\mathrm{P}(\mathrm{Z}<=\mathrm{z})$ two-tail & 0.873034 & 0.746207 & 0.53601 & 0.868256 & 0.642107 & 0.76503 \\
\hline & z Critical two-tail & 1.959964 & 1.959964 & 1.959964 & 1.959964 & 1.959964 & 1.959964 \\
\hline \multirow{4}{*}{$\begin{array}{l}\mathrm{Z} \text { value for } \\
\text { difference in } \\
\text { median for } 15 \\
\text { year period }\end{array}$} & $\mathrm{P}(\mathrm{Z}<=\mathrm{z})$ one-tail & 0.437987 & 0.375046 & 0.260561 & 0.434685 & 0.311511 & 0.371791 \\
\hline & z Critical one-tail & 1.644854 & 1.644854 & 1.644854 & 1.644854 & 1.644854 & 1.644854 \\
\hline & $\mathrm{P}(\mathrm{Z}<=\mathrm{z})$ two-tail & 0.875974 & 0.750093 & 0.521122 & 0.86937 & 0.623022 & 0.743582 \\
\hline & z Critical two-tail & 1.959964 & 1.959964 & 1.959964 & 1.959964 & 1.959964 & 1.959964 \\
\hline
\end{tabular}




\begin{tabular}{|c|c|c|c|c|c|c|c|}
\hline \multicolumn{8}{|l|}{ Continued } \\
\hline \multirow{4}{*}{$\begin{array}{l}\mathrm{Z} \text { value for } \\
\text { difference in } \\
\text { mean for } 20 \\
\text { year period }\end{array}$} & $\mathrm{P}(\mathrm{Z}<=\mathrm{z})$ one-tail & 0.370626 & 0.24992 & 0.101912 & 0.365219 & 0.173472 & 0.275591 \\
\hline & z Critical one-tail & 1.644854 & 1.644854 & 1.644854 & 1.644854 & 1.644854 & 1.644854 \\
\hline & $\mathrm{P}(\mathrm{Z}<=\mathrm{z})$ two-tail & 0.741251 & 0.49984 & 0.203824 & 0.730437 & 0.346944 & 0.551182 \\
\hline & z Critical two-tail & 1.959964 & 1.959964 & 1.959964 & 1.959964 & 1.959964 & 1.959964 \\
\hline \multirow{4}{*}{$\begin{array}{l}\mathrm{Z} \text { value for } \\
\text { difference in } \\
\text { median for } 20 \\
\text { year period }\end{array}$} & $\mathrm{P}(\mathrm{Z}<=\mathrm{z})$ one-tail & 0.371802 & 0.251789 & 0.102544 & 0.366257 & 0.173583 & 0.274815 \\
\hline & z Critical one-tail & 1.644854 & 1.644854 & 1.644854 & 1.644854 & 1.644854 & 1.644854 \\
\hline & $\mathrm{P}(\mathrm{Z}<=\mathrm{z})$ two-tail & 0.743603 & 0.503578 & 0.205089 & 0.732513 & 0.347166 & 0.549629 \\
\hline & z Critical two-tail & 1.959964 & 1.959964 & 1.959964 & 1.959964 & 1.959964 & 1.959964 \\
\hline \multirow{4}{*}{$\begin{array}{l}\mathrm{Z} \text { value for } \\
\text { difference in } \\
\text { mean for } 23 \\
\text { year period }\end{array}$} & $\mathrm{P}(\mathrm{Z}<=\mathrm{z})$ one-tail & 0.486365 & 0.471146 & 0.444333 & 0.484797 & 0.457901 & 0.472976 \\
\hline & z Critical one-tail & 1.644854 & 1.644854 & 1.644854 & 1.644854 & 1.644854 & 1.644854 \\
\hline & $\mathrm{P}(\mathrm{Z}<=\mathrm{z})$ two-tail & 0.97273 & 0.942293 & 0.888665 & 0.969595 & 0.915802 & 0.945951 \\
\hline & z Critical two-tail & 1.959964 & 1.959964 & 1.959964 & 1.959964 & 1.959964 & 1.959964 \\
\hline \multirow{4}{*}{$\begin{array}{l}\mathrm{Z} \text { value for } \\
\text { difference in } \\
\text { median for } 23 \\
\text { year period }\end{array}$} & $\mathrm{P}(\mathrm{Z}<=\mathrm{z})$ one-tail & 0.484322 & 0.476576 & 0.442685 & 0.492345 & 0.458326 & 0.465706 \\
\hline & z Critical one-tail & 1.644854 & 1.644854 & 1.644854 & 1.644854 & 1.644854 & 1.644854 \\
\hline & $\mathrm{P}(\mathrm{Z}<=\mathrm{z})$ two-tail & 0.968645 & 0.953153 & 0.885371 & 0.984691 & 0.916653 & 0.931412 \\
\hline & z Critical two-tail & 1.959964 & 1.959964 & 1.959964 & 1.959964 & 1.959964 & 1.959964 \\
\hline
\end{tabular}

Table 5. Exhibiting differences between rates in different maturity months.

\begin{tabular}{|c|c|c|c|c|c|c|c|}
\hline & & $1 \mathrm{v} / \mathrm{s} 3$ months & $1 \mathrm{v} / \mathrm{s} 6$ months & $1 \mathrm{v} / \mathrm{s} 12$ months & 3 v/s 6 months & $3 \mathrm{v} / \mathrm{s} 12$ months & $6 \mathrm{v} / \mathrm{s} 12$ months \\
\hline \multirow{4}{*}{$\begin{array}{l}\mathrm{Z} \text { value for } \\
\text { difference in } \\
\text { mean for } 5 \\
\text { year period }\end{array}$} & $\mathrm{P}(\mathrm{Z}<=\mathrm{z})$ one-tail & 0.486365 & 0.471146 & 0.444333 & 0.484797 & 0.457901 & 0.472976 \\
\hline & z Critical one-tail & 1.644854 & 1.644854 & 1.644854 & 1.644854 & 1.644854 & 1.644854 \\
\hline & $\mathrm{P}(\mathrm{Z}<=\mathrm{z})$ two-tail & 0.97273 & 0.942293 & 0.888665 & 0.969595 & 0.915802 & 0.945951 \\
\hline & z Critical two-tail & 1.959964 & 1.959964 & 1.959964 & 1.959964 & 1.959964 & 1.959964 \\
\hline \multirow{4}{*}{$\begin{array}{l}\mathrm{Z} \text { value for } \\
\text { difference in } \\
\text { median for } 5 \\
\text { year period }\end{array}$} & $\mathrm{P}(\mathrm{Z}<=\mathrm{z})$ one-tail & 0.484322 & 0.476576 & 0.442685 & 0.492345 & 0.458326 & 0.465706 \\
\hline & z Critical one-tail & 1.644854 & 1.644854 & 1.644854 & 1.644854 & 1.644854 & 1.644854 \\
\hline & $\mathrm{P}(\mathrm{Z}<=\mathrm{z})$ two-tail & 0.968645 & 0.953153 & 0.885371 & 0.984691 & 0.916653 & 0.931412 \\
\hline & z Critical two-tail & 1.959964 & 1.959964 & 1.959964 & 1.959964 & 1.959964 & 1.959964 \\
\hline
\end{tabular}

\section{Conclusion}

The conclusions that can be derived from this paper are that although there are structural changes in the average LIBOR trend, it does not affect the different period floating swaps rates because all the four above mentioned swap rates are highly correlated to one another and treads in close tandem. This result does not change when is calculated in entirety or by breaking the samples into sub-samples. The forecasted rates based on the historical rates will be of useful in determining what position to take.

\section{References}

[1] Brown, K.C., Harlow, W.V. and Smith, D.J. (1994) An Empirical Analysis of Interest Rate Swap Spreads. The Journal of Fixed Income, 3, 61-78. http://dx.doi.org/10.3905/jfi.1994.408095

[2] Kiff, J., Ron, U. and Ebrahim, S. (2001) The Federal Government’s Use of Interest Rate Swaps and Currency Swaps. 
Bank of Canada Review, 23-34.

[3] James, B. and Chen, A.H. (1986) An Economic Analysis of Interest Rate Swaps. Journal of Finance, 41, 645-656. http://dx.doi.org/10.1111/j.1540-6261.1986.tb04527.x

[4] Hull, J.C. (2005) Options, Futures and Other Derivatives. Prentice Hall publishers, Upper Saddle River.

[5] Grinblatt, M. (2001) An Analytic Solution for Interest Rate Swap Spreads. International Review of Finance, 2, 113149. http://dx.doi.org/10.1111/1468-2443.00022

[6] Sheridan, T. (1992) Interest Rate Swaps and Corporate Financing Choices. Journal of Finance, 47, 1503-1516. http://dx.doi.org/10.1111/j.1540-6261.1992.tb04667.x

[7] Stuart, T. (1987) Swaps: A Zero Sum Game? Financial Management, 16, 15-21. http://dx.doi.org/10.2307/3665544

[8] Wall, L.D. and Pringle, J.J. (1989) Alternative Explanation of Interest Rate Swap: A Theoretical and Empirical Analysis. Financial Management, 18, 59-73. http://dx.doi.org/10.2307/3665893

[9] Duffie, D. (1999) Credit Swap Valuation. Financial Analysts Journal, 55, 73-87. http://dx.doi.org/10.2469/faj.v55.n1.2243 